\title{
DETERMINING THE ATTITUDES OF STORE MANAGERS FOR GREEN MARKETING MIX: KOCAEU SHOPPING CENTER APPLICATION
}

DOI: 10.17261/Pressacademia.2020.1249

PAP- V.11-2020(21)-p.101-109

Mualla Akcadag ${ }^{1}$, Omer Ellibes ${ }^{2}$

${ }^{1}$ Sivas Cumhuriyet University, Faculty of Economics and Administrative Sciences, Sivas, Turkey. makcadag@cumhuriyet.edu.tr, ORCID: 0000-0002-0785-3976

${ }^{2}$ Sivas Cumhuriyet University, The Institute Of Social Sciences, International Trade and Logistics. Master Program, Sivas, Turkey. omerellbes1903@gmail.com, ORCID: 0000-0003-3957-2164

To cite this document

Akcadag M., Ellibes O., (2020). Determining the attitudes of store managers for green marketing mix: Kocaeli shopping center application . PressAcademia Procedia (PAP), V.11, p.101-109

Permanent link to this document: http://doi.org/10.17261/Pressacademia.2020.1249

Copyright: Published by PressAcademia and limited licensed re-use rights only.

\begin{abstract}
Purpose- With the globalization, the advancement of technology and the development of industrialization, the damage to the environment continues to increase. Business managers, adoption of environmentally friendly practices plays an active role in sustainable competition. From this point of view, it is aimed to determine the attitudes of the store managers operating in the shopping center towards the green marketing mix by determining whether these attitudes differ in terms of demographic characteristics.

Methodology- A survey was conducted with 71 store managers in a shopping center in Kocaeli. The main mass of the research consists of the managers of the businesses operating in the shopping center in Kocaeli. The data obtained were analyzed with SPSS statistical software. Findings- As a result of the study, the attitudes of the store managers towards the green marketing mix do not differ significantly in terms of gender, age, education position and income.

Conclusion- There are significant differences in terms of gender, income, position and age in some expressions within the scope of green product, green price, green promotion and green distribution of store managers. There was no significant difference in terms of education.

Keywords: Marketing, green marketing, green marketing mix,

JEL Codes: M3, M30, M31.

\section{MAĞAZA YÖNETICILERININ YEŞIL PAZARLAMA KARMASINA YÖNELIK TUTUMLARININ BELIRLENMESI: KOCAELI ALIŞVERIŞ MERKEZI UYGULAMASI}

\section{ÖZET}

Amaç- Küreselleşme, teknolojinin ilerlemesi, sanayileşmenin gelişmesi ile çevreye verilen zarar daha da artmaya devam etmektedir. İşletme yöneticilerinin, çevreye zarar vermeyen uygulamaları benimsemeleri sürdürülebilir rekabet etmede etkin bir rol oynamaktadır. Buradan hareketle bu çalışma ile alışveriş merkezinde faaliyet gösteren mağaza yöneticilerinin yeşil pazarlama karmasına yönelik tutumlarının belirlenerek bu tutumlarının demografik özellikleri açısından bir farklıık gösterip göstermediğini belirlemek amaçlanmaktadır.

Yöntem- Bu amaçla Kocaeli ilinde bulunan bir alışveriş merkezindeki 71 mağaza yöneticisi ile anket çalışması yapılmıştır. Araştırmanın ana kütlesini Kocaeli ilinde bulunan alışveriş merkezinde faaliyet gösteren mağazaların yöneticileri oluşturmaktadır. Elde edilen veriler SPSS istatiksel paket programı ile analiz edilmiştir.

Bulgular- Çalışma sonucunda mağaza yöneticilerinin yeşil pazarlama karmasına yönelik tutumları ile cinsiyet, yaş, eğitim pozisyon ve gelire göre genel olarak anlamlı bir farklılık taşımamaktadır.

Sonuç- Ancak mağaza yöneticilerinin, yeşil ürün, yeşil fiyat, yeşil tutundurma ve yeşil dağıtım kapsamındaki bazı ifadelerde cinsiyet, gelir, pozisyon ve yaş açısından anlamlı farklııılar tespit edilmiştir. Eğitim açısından anlamlı bir farklıık bulunamamıştır.

Anahtar Kelimeler: Pazarlama, yeşil pazarlama, yeşil pazarlama karması.

JEL Kodları: M3, M30, M31. 


\section{GíRiş}

Müşteri istek ve ihtiyaçlarının karşılanması için ürünün oluşturulması, fiyatının belirlenmesi, dağıtımın ve tutundurmanın gerçekleştirilmesi pazarlama olarak ifade edilmektedir. İşletmelerin, pazarlama faaliyetlerini gerçekleştirirken müşteri memnuniyeti, müşteri ta tmini, müşteri bağ ılığı, müşteri sadakati, kar etme, rekabette sürdürülebilir olma, toplumsal fayda sağlama gibi birçok amacı bulunmaktadır. Yeşil pazarlama, bu amaçlardan özellikle toplumsal fayda sağlama etkeni üzerinde duran işletmelerin dikkatini çekmektedir.

Sanayileşmenin gelişmesi, teknolojinin ilerlemesi, küreselleşme gibi birçok etkenden dolayı çevreye verilen zarar artmaya devam etmektedir. Bu durum küresel çevre sorunlarını da beraberinde getirmiştir. Çevre konusunda daha bilinçli hale gelen tüketiciler karşısında, işletmelerin bu zorlu rekabet ortamında ayakta kalabilmeleri için toplumsal bilince ve sosyal sorumluluğa sahip olmaları zorunluluğu ortaya çıkmıştır (Varinli, 2000). Dolayısıyla işletmelerin rekabet etmede sürdürülebilir olma çabaları, çevreye duyarlı olma düşünceleri ve tüketicilerin çevre bilincine sahip işletmeleri tercih etmeleri ile pazarlama sektöründe yeşil pazarlama kavramı önem kazanmaya başlamıştır.

Yeşil pazarlama kavramı ilk kez 1970' li yıllarda ortaya atılmıştır. Kotler ve Zaltmann (1971) toplumsal pazarlama kavramını açıklarken pazarlama tekniklerinin oluşturulmasında çevreye duyarlı ve çevreyi koruyan, ticari fayda yerine toplum yararı sağlamanın gerekliliği gibi açıklamalarla yeşil pazarlamanın temelini atmışlardır (Doğan, 2018:31). 1975 yılında da AMA (Amerikan Pazarlama Birliği) tarafından düzenlenen "Ekolojik Pazarlama" konulu seminerde yeşil pazarlama tanımlanmıştır. Bu tanıma göre yeşil pazarlama, pazarlama fa aliyetlerinin çevre kirliliği, enerji tüketimi ve diğer kaynakların tüketimi üzerine olumlu veya olumsuz etkileri ile ilgili bir çalışma olarak ifade edilmiştir (Kinoti, 2011: 264). Peattie ise (1995) yeşil pazarlamayı; tüketici ve toplum ihtiyaçlarının karlı ve sürdürülebilir bir şekilde belirlenmesi, tahminlenmesi ve karşılanmasından sorumlu bütünsel bir yönetim süreci olarak tanımlamıştır. Fuller de (1999) yeşil pazarlamayı ürünlerin geliştirilmesi, fiyatlandırılması, tutundurulması ve dağıımında planlama, yürütme ve denetleme süreçlerinin tüketici ihtiyaçlarının karşılanması, kurumsal hedeflerin ve sürecin ekosistemlerle uyumlu olmasının sağlanması gibi kriterlere uygun olarak ele alınması olarak ifade etmiştir. Yeşil pazarlama, yeşil ürün, yeşil fiyat, yeşil tutundurma ve yeşil dağıtımdan oluşmaktadır. Hizmet sektöründe de insan, süreç ve fiziksel kanıtlar yeşil pazarlamanın diğer elamanlarıdır. Müşteri istek ve ihtiyaçlarını gerçekleştirirken oluşturulan yeşil ürün, yeşil fiyat, yeşil dağıtım ve yeşil tutundurma çabaları ise yeşil pazarlama karması olarak ifade etmek mümkündür. Yeşil ürün, üretim sürecinde zararlı etkilerin ortadan kaldırılarak üretilen olarak belirtmek mümkündür ( Chang, 2016). Yeşil fiyat ise yeşil pazarlama karmasındaki en etkili faktörlerden biridir. Birçok müşterinin satın almak istediği ürünün ekstra bir değer taşıdığında o ürüne daha çok ödemeyi kabul edeceğini düşünen araştırmacıların olduğu gibi (Peattie, 2001; Sharma, 2011; Boztepe, 2012; Pedro ve Lemke, 2013; Murali ve ark., 2016) yeşil ürünlerin fiyatlarının yüksek olduğunda müşterilerin satın alma olasılıklarının düşeceği görüşünde olan bir çok araştırmacı da bulunmaktadır (Blend ve Van Ravenswaay, 1999; Suki, 2016). Tüm bu farklılıkları gözönünde bulunduran işletmelerin yeşil fiyatı belirlerken rakiplerin fiyatlarına benzer fiyatlar belirlemesi daha uygun olacaktır (Soonthonsmai, 2007). Yeşil pazarlamanın bir diğer elemanı olan yeşil tutundurma ise, müşterilerin yeşil ürün satın almaları için tutundurma bileşenlerini kullanarak ikna etme çabaları olarak ifade edilmektedir (Doğan, 2018). Son olarak yeşil dağıtım ise, ürünlerin dağıtımı sırasında daha az yakıt kullanılması, müşterilerin ürünlere daha zamanda ulaşmasına sağlayacak yerlerde satılmasını içermektedir (Özcan ve Özgül, 2019).

Yeşil pazarlama ve yeşil pazarlama karması ile ilgili yapılan bu farklı tanımların ortak yanları, çevreye duyarlı, toplum bilincine sahip, sürdürülebilir rekabet etmek isteyen işletmelerin, tüm faaliyetlerini bu amaçlar doğrultusunda gerçekleştirmeleridir. Günümüzde çevre kanunları, bilinçli tüketicilerin artması ve sosyal sorumlulukların öne çıkması işletme, işletme yöneticileri ve pazar yöneticileri tarafından önemli bir konu haline gelmiştir (Rex ve Baumann, 2007). Toplum ve sosyal sorumluluk özelliği taşıyan işletmeler üretim öncesi, üretim, satış, satış sonrası faaliyetlerinde doğa ile uyumlu teknolojiler kullanmaları zorunlu hale gelmektedir. Buradan hareketle bu çalışma ile Kocaeli ilinde bulunan bir alış veriş merkezinin mağaza yöneticilerinin günümüzde son derece önemli olan yeşil pazarlama tutumlarını belirlemek ve yeşil pazarlama karması tutumlarının demografik özellikler bakımından farklılık taşıyıp taşımadığını belirlemek amaçlanmıştır.

\section{LITERATÜR I NCELEMESI}

Yeşil pazarlama ile ilgili yapılan literatür taramasında, yeşil pazarlamanın sadece faaliyet olarak değil aynı zamanda bir felsefe olarak da görülmesi gerekliliği üzerinde durulan çalışma göze çarpmaktadır. Çalışmanın uygulama bölümü, İspanya da Ecolabel etiketi alan firmalarla yapılmıştır. Çalışma sonucunda Ecolabel etiketi kullanan firmaların bu etiketleri sadece pazarlama aracı olarak değil aynı za manda firmaların yeşil pazarlama felsefelerinin de yansımaları olduğu vurgulanmıştır (Chamorro ve Bañegi, 2006:21).

Bir diğer çalışma ise yeşil pazarlamaya ilişkin literatürden derlenen bilgilerin sunulduğu araştırmadır. Çalışmada yeşil paza rlama kavramının anlamı ve içeriği, geleneksel pazarlama anlayışından farkları, pazarlama karmasının yeşil pazarlama açısından değerlendirilmesi, yeşil pazarlamanın düzeyleri gibi konular açıklanmıştır. Ayrıca çalışmada uygulama bölümü de yer almaktadır. Çalışmanın uygulama bölümünde Karadeniz Teknik Üniversitesi İktisadi ve İdari Bilimler Fakültesi İşletme Bölümü öğrencileri üzerinde yapılan bir araştırmanın sonuçlarına yer verilmiştir. Bu sonuçlara göre, öğrencilerin çoğunluğunun yeşil pazarlama konusundaki davranışlarının genel olarak sürekli ve sistemli değil, zaman zaman ortaya çıkan davranışlar olduğu belirtilmiştir (Ayyıldız ve Genç, 2008).

Yeşil pazarlamanın tüketiciler açısından incelendiği çalışmada ise tüketicilerin çevre bilincini ve çevreye duyarlı ürünleri kullanma eğilimlerini belirlemek amacıyla Sivas ilinde yaşayan 362 kişiye yüz yüze anket uygulanmıştır. Çalışmada, tüketicilerin daha az kirlilik yaratan, atıkları azaltan, daha fazla geri dönüşüm sağlayan yenilenebilir kaynakların üretimde daha fazla kullanımını ve ürünlerin ekosistem için daha güvenli olmasını talep ettikleri belirtilmiştir. Makalede, tüketicilerin çevrenin korunması konusunda gittikçe daha fazla bilinçlenmeleri şirket yöneticileri ve özellikle pazarlama yöneticileri için daha fazla önemsenmesi gereken bir konu haline geldiği vurgulanmıştır (Karaca, 2013).

Bir diğer çalışmada ise yeşil pazarlama ve sosyal sorumluluk kavramlarının önemi üzerinde durulmuştur. Tanımlayıcı çalışmanın sonucunda pazar odaklı işletmelerin, müşterilerin ve toplumun sosyal beklentilerini karşılamak için sosyal sorumluluğa doğru hareket etmeleri dolayısıyla yeşil pazarlamanın gerekliliğinin esas olduğu belirtilmiştir (Sudhalakshmı ve Chınnadoraı, 2014:111). 
Kavramsal olarak yapılan çalışmada ise Malezya' da ISO 14001 Çevre Yönetim Sistemi onaylı firmaların yeşil pazarlama stratejilerinin firmalarının performansı üzerindeki etkilerini incelemek amaçlanmıştır. Çalışmada, bu firmalarınyeşil pazarlama stratejilerine önem verdikleri ve dünya çapında yeşil ürünlerin hızlı büyümesi göz önüne alındığında, pazarlamacıların, tüketici ihtiyaç ve isteklerini gerçekleştirme de yeşil pazarlama stratejisini belirlemeleri gerektiği sonucuna varılmıştır (Hasan ve Ali, 2015).

Çin’ de yeşil pazarlama ve tüketicilerin ilk kez analiz edildiğinin belirtildiği çalışmada ise Çin'in yeşil pazarlama karması, sanayi sektörleri ve yeşil tüketim arasındaki ilişkilerin ayrıntılı analizi, sosyal değişim endişeleri belirtilmiştir. Çalışmada yeşil pazarlama için rekabet baskısı, hükümet politikası, pazar fırsatı olarak üç ana tetikleyici belirlenmiştir (Zhu ve Sarkis, 2016).

Konuyla ilgili bir diğer çalışmada ise yeşil pazarlamanın sürdürülebilir iş stratejisi için önemli bir araç haline geldiğini, şirketlerin daha iyi iş performansı elde etmek için yeşil pazarlama uygulamalarını benimsedikleri belirtilmiştir. Bununla birlikte, çalışmada üç boyuttan oluşan yeşil pazarlama yönelimi (stratejik yeşil pazarlama yönelimi, taktik yeşil pazarlama yönelimi ve iç yeşil pazarlama yönelimi) yapısı tanıtılmaktadır (Papadas vd., 2017).

Simão ve Lisboa (2017), tarafından yapılan çalışmada ise yeşil markanın önemine değinilmiştir. Çalışmada sürdürülebilirlik konusunda çabaları kabul görmüş bir marka olan Toyota örneğini incelenmiştir. Ayrıca araştırmada yeşil pazarlama stratejisinin, piyasayı bölümle re ayırmaya, yeşil ürünler geliştirmeye, yeşil bir lojistik uygulamaya, yönetmeye, yeşil bir iletişim seçmeye, yeşil ortaklıklara yatırım yapmaya ve yeterli pazarlama karmasına sahip olmaya odaklanması gerektiği sonucuna varılmıştır (Simão ve Lisboa, 2017).

Yeşil pazarlama ve tüketicilerle ilgili bir diğer çalışmada ise çalışan bireylerin yeşil ürün reklamlarına yönelik tutumlarını belirlemeye yönelik araştırmadır. Çalışmada çalışan tüketicilerin, yeşil ürün reklamlarına yönelik tutumlarının cinsiyet, yaş, eğitim gibi birçok demografik özelliklerì açısından farklılık taşıdığı bulgusuna varılmıştır (Benli vd., 2017).

Yeşil pazarlamanın, bireysel düzey tüketici davranış teorilerini sentezlemek ve kapsamlı bir genel bakış olarak ifade edildiğ i çalışmada ise yeşil ürünlerin pazarlamasının, yeşil olmayan ürünlerin pazarlamasından farklı yaklaşımlar gerektirdiği belirtilmiştir. Çalışmada, az sayıda tüketicinin yeşil ürünler için daha fazla ödeme yapacağı belirtilmiştir (Groening vd., 2018).

Tanımlayıc bir diğer çalışmada ise öncelikle yeşil pazarlama kavramı hakkında bilgi verilmiştir. Daha sonra hazır giyim sektöründe yeşil pazarlama uygulamaları incelenerek, sektördeki işletmelere önerilerde bulunulmuştur. Makalede, tüketicilerin çevre konusunda bilinçlenmesi ve duyarlı hale gelmesi işletmeleri de bu konuda daha duyarlı olmaya zorladığı belirtilmiştir. Yeşil ürün ve pazarlama çalışmalarında maliyeti en aza indirgeyen, ancak verimliliği artıran yöntemlerin uygulanmasının önemli olduğu ifade edilmiştir. Çalışmada, işletmelerin, sosyal sorumluluk bilinci ile hareket ederek, doğayla uyumlu ürünler üretmesi ve yeşil pazarlama gibi modern pazarlama yöntemlerinin uygulanması, hem işletmeler hem de müşteriler için faydalı olabileceği sonucuna varılmıştır (Öndoğan, 2018).

Yeşil pazarlamanın firma performansı üzerindeki etkisini ölçmek için yapılan bir diğer çalışma ise yöneticiler üzerinde yapılan nadir çalışmalardandır. Çalışmada yeşil pazarlamanın firma performansı üzerindeki etkisini ölçmek için müşteri sadakati, müşteri me mnuniyeti, kurumsal itibar, iş gören memnuniyeti ölçeklerinden yararlanılmıştır. Çalışma yöneticilerin yeşil pazarlama faaliyetlerini uyguladıkları varsayımına dayanılarak yapıımıştır. Araştırma sonucunda yeşil pazarlamanın firmaların marka değerleri ve kurumsal itibarları üzerinde etkili olduğu belirtilmiştir. Ayrıca çalışmada yeşil pazarlamanın firmaların finansal ve finansal olmayan performansları üzerinde olumlu etkisi olduğu vurgulanmıştır (Doğan, 2018:80).

Bir diğer çalışmada ise Dünya' da ve Türkiye' de yeşil pazarlama uygulamalarına değinilmiştir. Çalışmada yeşil pazarlama uygulamalarına örnek verilerek işletmelerin tüketici ve çevre yararına ne tür faaliyetlerde bulundukları incelenmeye çalışılmıştır (Kocaşahin, 2019).

Sürdürülebilir rekabet etmede önemli olan unsurlardan olan yeşil pazarlama ile ilgili birçok çalışma mevcuttur. Çalışmaların büyük bir çoğunluğunu yeşil pazarlamanın tüketiciler üzerindeki etkisini belirlemeye yönelik araştırmalar oluşturmaktadır. Konuyla ilgili diğer çalışmalar ise yeşil pazarlama kavramını açıklayıcı ve tanımlayıcı araştırmalardır. Yapılan literatür taramasında yeşil pazarlamanın yöneticiler açısından değerlendirildiği çok kısıtlı çalışma bulunmaktadır. Bu çalışmalar yeşil pazarlamanın firma performansı üzerindeki etkisini belirmeye yönelik çalışmalardır. Bahsi geçen sınırlı çalışmalarda katılımcı yöneticilerinin firmalarının büyük olduğu düşüncesiyle yeşil pazarlama uyguladıkları varsayımına dayanmaktadır. Çalışmada kullanılan yeşil pazarlama karması ölçeği ile ilgili ifadelere mağaza yöneticilerinin, y öneticilik yaptıkları mağaza için yeşil ürün, yeşil fiyat, yeşil dağıtım ve yeşil tutundurma faaliyetlerine göre verdikleri kararlar doğrultusunda yanıt vermeleri istenmiştir. Dolayısıyla aslında mevcut çalışmalar yöneticilerin yeşil pazarlama ile ilgili tutumlarını belirlemeye yönelik olmadığından buradan hareketle bu çalışma ile mağaza yöneticilerin yeşil pazarlamaya yönelik tutumlarının bazı demografik özellikleri ile farklılık olup olmadığını anlamaya yönelik olarak yapılmıştır. Bu anlamda literatürdeki boşluğun doldurulması hedeflenmektedir.

\section{YÖNTEM}

Sürdürülebilir rekabet etmede önemli hale gelen yeşil pazarlama işletmeler için kilit bir öneme sahiptir. Buradan hareketle bu çalışma ile Kocaeli ilinde bulunan bir alış veriş merkezindeki mağaza yöneticilerinin yeşil pazarlama karmasına yönelik tutumlarının demografik özellikleri (cinsiyet, yaş, gelir vb.) açısından bir farklılık olup olmadığının belirlenmesi amaçlanmıştır. Bu amaçla aşağıdaki şekil 1' de gösterilen araştıma modeli oluşturulmuştur. Araştırmanın ana kütlesini Kocaeli ilinde bulunan bir alış veriş merkezindeki mağazaların yöneticileri oluşturmakadır. Ilgili alış veriş merkezinde 76 mağaza yöneticisi hali hazırda görev yapmaktadır. Bu 76 yöneticinin tamamına anket yapılmak istenmiş ancak 71 tanesi anketi doldurmayı kabul etmiş ve anket geri dönüş oranı \% 93 olarak hesaplanmıştır.

Araştırmada veritoplamak üzere oluşturulan anket formu ikibölümden oluşmaktadır. Birinci bölümde yöneticilerin yeşil pazarlama karmasına yönelik düşüncelerini belirlemeye yönelik 16 ifadeden oluşan yeşil pazarlama karması ölçeği bulunmaktadır. Ölçekte 1 "kesinlikle katılmıyorum", 5 "kesinlikle katılıyorum" u ifade etmektedir. 
Yeşil pazarlama karması ölçeği olarak Çoban ve Sönmez (2014) çalışmalarındaki yeşil pazarlama karmasına yönelik tutum ölçeği kullanılmıştır. Ölçeğin güvenirlilik analizi için Cronbach Alpha Cofficient'a başvurulmuştur. Ölçeğinin güvenilirliği, cronbach alfa değeri 0,756 olduğu bu sonuçla da ölçeğin yeterli düzeyde güvenilir olduğu görülmektedir. ikinci bölümde ise katılımcıların demografik özelliklerini belirlemeye yönelik sorular (cinsiyet, yaş, eğitim, gelir ve pozisyon) yer almaktadır.

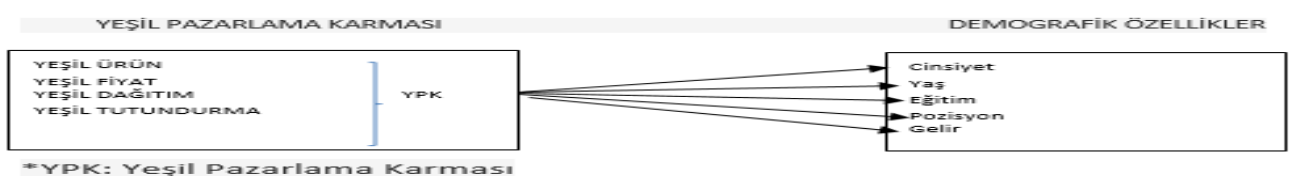

-YPK: Yeşil Pazarlama Karmas

Sekil 1. Arasturma modeli

Bu kapsamda aşağıdaki hipotezler geliştirilmiştir:

$\mathrm{H}_{1}$ Yöneticilerin Yeşil Pazarlama Karması ile ilgili tutumları ile cinsiyetleri açısından anlamlı farklılık vardır.

$\mathrm{H}_{2}$ Yöneticilerin Yeşil Pazarlama Karması ile ilgili tutumları ile yaşları açısından anlamlı bir farklılık vardır.

$\mathrm{H}_{3}$ Yöneticilerin Yeşil Pazarlama Karması ile ilgili tutumları ile eğitimleri açısından anlamlı bir farklılık vardır.

$\mathrm{H}_{4}$ :Ÿneticilerin Yeşil Pazarlama Karması ile ilgili tutumları ile pozisyonları açısından anlamlı bir farklılık vardır.

$\mathrm{H}_{5}$ : Yöneticilerin Yeşil Pazarlama Karması ile ilgili tutumları ile gelirleri açısından anlamlı bir farklılık vardır.

\subsection{Demografik Özellikler}

Mağaza yöneticilerinin demografik bilgilerinin yer aldığı Tablo 1.'e göre, erkek yöneticilerin \% 60,6 ile ağırlıkta olduğu görülmektedir. Yaş değişkenine bakıldığında ise 30 - 39 yaş aralığının en yüksek (\% 46,5) olduğu anlaşımaktadır. Yöneticilerin, pozisyon olarak en yüksek orta düzey yöneticilerden (\% 59,2), eğitimde, lise öğrenimin (\% 47) son olarak da gelir değişkeninde de en fazla 2501 - 3500 TL gelire sahip oldukları anlaşımaktadır. Demografik özelliklere ait bilgiler Tablo 1.' de aşağıdadır.

Tablo 1: Demografik Özellikler

\begin{tabular}{|c|c|c|c|}
\hline Değişkenler & Kategoriler & $\mathbf{N}$ & (\%) \\
\hline \multirow[b]{2}{*}{ Cinsiyet } & Kadın & 28 & 39,4 \\
\hline & Erkek & 43 & 60,6 \\
\hline \multirow[t]{3}{*}{ Yaş } & $20-29$ & 18 & 25,4 \\
\hline & $30-39$ & 33 & 46,5 \\
\hline & $40-49$ & 20 & 28,2 \\
\hline \multirow[t]{3}{*}{ Pozisyon } & Orta Düzey Yönetici & 42 & 59,2 \\
\hline & Üst Düzey Yönetici & 16 & 22,5 \\
\hline & İdari Personel & 13 & 18,3 \\
\hline \multirow[t]{3}{*}{ Eğitim } & Lise & 34 & 47 \\
\hline & Ön lisans & 19 & 26,8 \\
\hline & Lisans & 18 & 25,4 \\
\hline \multirow[t]{4}{*}{ Gelir } & $1500-2500 \mathrm{TL}$ & 7 & 9,9 \\
\hline & $2501-3500 \mathrm{TL}$ & 33 & 46,5 \\
\hline & 3501 TL ve Üzeri & 31 & 43,7 \\
\hline & Toplam & 71 & 100,0 \\
\hline
\end{tabular}

\section{BULGULAR}

Tanımlayııı nitelik taşıyan araştırma için anket yöntemi kullanılarak toplanan veriler SPSS prog ramında analiz edilmiştir. Araştırmada verilerin analizinde demografik özelliklerin belirlenmesinde frekans ve yüzdelik tablolarından yararlanılırken yeşil pazarlama karması değişkeninin demografik özellikler açısından bir farklılık olup olmadığının anlaşılması için ise T - testi ve One - Way ANOVA testleri uygulanmıştır.

\subsection{Mağaza Yöneticile rin Yeşil Pazarlama Karmasına ilişkin Tutumları}

Kocaeli ilinde bulunan bir alış veriş merkezindeki mağaza yöneticilerinin yeşil pazarlama karması ile tutumları Tablo 2' de y er almaktadır. Bu bilgilere göre; yeşil ürün ile ilgili ifadelere verilen yanıtlar incelendiğinde, "Yeşil ürünlerin kıt kaynaklardan üretildiğini bildiğim için yeşil ürünleri bilinçli kullanırım" düşüncesine yöneticilerin 63' ü (\% 88,7) katılmaktadır. Yine yeşil ürün ile ilgili “Yeşil ürünü satın alırken ambalajındaki çevresel uyarılara dikkat ederim." şeklindeki ifadeye yöneticilerin 48' i (\% 67,6), "Alacağım ürünlerin içinde kimyasal katkı maddeleri olup olmadığına dikkat ederim." 54 yöneticinin $(\% 76,1)$ katıldığı görülmektedir. Yeşil ürün ile ilgili son olarak "Ürünün yenilenebilir olması ve çevreye daha az zarar vermesi önemlidir." ifadeye yöneticilerin 69' nun (\%97) katıldığı anlaşılmaktadır. Yöneticilerin yeşil ürün ile ilgili tutumlarının yeşil pazarlama karması tutum ölçeğini, tüketiciler açısından değerlendiren araştırmaların sonuçlarına benzerlik gösterdiği anlaşılmaktadır (Uysal, 2006; Aslan, 2007; Çoban ve Sönmez, 2014). 
Yöneticilerin yeşil fiyat tutumları ile ilgili yanıtlarına bakıldı̆̆ında ise "Yeşil ürün alışverişinde fiyatı ne olursa olsun, güvendiğim ürünü alırım." Ifadesine yöneticilerin 54' ü $(\% 76,1)$ katılmaktadır. "Çevreye zararlı bir ürünü fiyatı düşük olduğu için tercih etmem." Ifade sine 59 yönetici $(\% 83,1)$, "Çevreye dost yoldan üretilen, işlenen ve paketlenen ürünlere daha fazla ödeme yapmayı kabul ederim." ifadesine 46 yönetici (\% 64,8), "Yeşil ürün satın alırken markalar arası fiyat farklılıklarına her zaman dikkate alıım." ifadesine 61 yöneticinin (\% 85,9) katıldığı görülmektedir. "Yeşil ürünler uzak mağazalarda satılsa bile bu ürünleri satın almayı tercih ederim." ifadesine ise yöneticilerin 31' inin kararsR olduğu görülmektedir. Bu sonuçların literatür taraması sırasındaki ilk 4 ifadenin ilgili çalışmalara benzerlik gösterdiği (Uysal, 2006; Türk ve Gök, 2010; Çoban ve Sönmez, 2014) ancak yeşil fiyatla ilgili son ifadeye verilen yanıtların yöneticiler açııından kararsızım şeklindeki cevap verme ile farkllık göstermektedir.

Yöneticilerin yeşil dağıtım ile ilgili tutumlarına bakıldı̆ıında ise, ifadeye "Firmaların çevreye yönelik uyguladıkları; katı atıkların imhası, lojistik faaliyetlerde enerji kullanımının azaltılması gibi faaliyetleri uygulaması çevreye verdikleri önem den kaynaklanmaktadır.", 50 yönetici $(\% 70,4)$ katılmaktadır. Bir diğer ifadeye ise "Çevre kirliğinin en büyük nedenlerinden biri, ürünlerin taşınması ve dağıtılması sırasında ortaya çıkmaktadır." 41 yöneticinin katıldı̆ı anlaşılmaktadır. Yeşil fiyat ile ilgili son ifadeye ise 62 yöneticinin katıldığı görülmektedir. Buradan da anlaşıldı̆̆ı üzere yöneticilerin yeşil pazarlama karması içerisinde yer alan yeşil dağıtım konusunda olumlu anlamda duyarlı oldukları şeklinde ifade edilebilir. Katılımcıların yeşil tutundurma ile ilgili tutumlarına bakıldı̆̆ında ise, "Ürünün çevre dostu olduğu imajı veren mesajlara sonuna kadar güveniyorum.", 18 yöneticinin $(\% 25,4)$ kararsız olduğu, 41 yöneticinin ise $(\% 57,8)$ ifadeye katıldığı anlaşılmaktadır. Yeşil tutundurma ile ilgili bu ifadeye yöneticilerin bazılarının kararsız yönde yanıt verselerde yine çoğunluğunun ürünlerin çevre dostu şeklindeki imajlarına güvendikleri anlaşılmaktadır. Yeşil tutundurma ile ilgili ifadelerden en çok katılımın olduğu ifade ise "Firmaların çevreci a ktivitelerini anlatan mesajları onların çevrenin korunmasına katkıda bulunduklarının göstergesidir. "şeklindedir (54 yönetici; \% 76). Tablo 2' de de görüldüğü üzere yeşil tutundurma ile ilgili ifadelere çoğunlukla yöneticilerin katıldığı anlaşımaktadır.

Tablo 2: Mağaza Yöneticilerin Yeşil Pazarlama Karmasına İlişkin Tutumları

\begin{tabular}{|c|c|c|c|c|c|c|c|c|c|c|}
\hline \multirow{2}{*}{$\begin{array}{l}\text { İ̧̧letmelerin Yeşil Pazarlama Karmasına Yönelik Tutumlarının } \\
\text { Belirlenmesine Yönelik Ifadeler } \\
\text { Yeşil Ürün }\end{array}$} & \multicolumn{2}{|c|}{$\begin{array}{c}\text { Kesinlikle } \\
\text { Katılmı } \\
\text { yorum }\end{array}$} & \multicolumn{2}{|c|}{$\begin{array}{l}\text { Katılmı } \\
\text { yorum }\end{array}$} & \multicolumn{2}{|c|}{ Kararsızım } & \multicolumn{2}{|c|}{ Katılıyorum } & \multicolumn{2}{|c|}{$\begin{array}{l}\text { Kesinlikle } \\
\text { Katılıyorum }\end{array}$} \\
\hline & $\mathrm{n}$ & $\%$ & $n$ & $\%$ & $n$ & $\%$ & $n$ & $\%$ & $\mathrm{n}$ & $\%$ \\
\hline $\begin{array}{l}\text { 1.Yeşil ürünlerin kıt kaynaklardan üretildiğini bildiğim için yeşil } \\
\text { ürünleri bilinçli kullanırım. }\end{array}$ & 1 & 1,4 & 1 & 1,4 & 6 & 8,5 & 17 & 23,9 & 46 & 64,8 \\
\hline $\begin{array}{l}\text { 2. Yeşil ürünü satın alırken ambalajındaki çevresel uyarılara dikkat } \\
\text { ederim. }\end{array}$ & 3 & 4.2 & 9 & 12.7 & 11 & 15.5 & 20 & 28.2 & 28 & 39.4 \\
\hline $\begin{array}{l}\text { 3. Alacağım ürünlerin içinde kimyasal katkı maddeleri olup } \\
\text { olmadığına dikkat ederim. }\end{array}$ & 1 & 1.4 & 13 & 18.3 & 3 & 4.2 & 22 & 31.0 & 32 & 45.1 \\
\hline $\begin{array}{l}\text { 4. Ürünün yenilenebilir olması ve çevreye daha az zarar vemesi } \\
\text { önemlidir. }\end{array}$ & - & - & 1 & 1.4 & 1 & 1.4 & 29 & 40.8 & 40 & 56.3 \\
\hline Yeşil Fiyat & $\mathrm{n}$ & $\%$ & $\mathrm{n}$ & $\%$ & $\mathrm{n}$ & $\%$ & $\mathrm{n}$ & $\%$ & $\mathrm{n}$ & $\%$ \\
\hline $\begin{array}{l}\text { 5. Yeşil ürün alışverişinde fiyatı ne olursa olsun, güvendiğim ürünü } \\
\text { alırım. }\end{array}$ & 2 & 2.8 & 4 & 5.6 & 11 & 15.5 & 21 & 29.6 & 33 & 46.5 \\
\hline 6. Çevreye zararlı bir ürünü fiyatı düşük olduğu için tercih etmem. & 1 & 1.4 & 7 & 9.9 & 4 & 5.6 & 12 & 16.9 & 47 & 66.2 \\
\hline $\begin{array}{l}\text { 7. Çevreye dost yoldan üretilen, işlenen ve paketlenen ürünlere daha } \\
\text { fazla ödeme yapmayı kabul ederim. }\end{array}$ & 2 & 2.8 & 6 & 8.5 & 17 & 23.9 & 22 & 31.0 & 24 & 33.8 \\
\hline $\begin{array}{l}\text { 8. Yeşil ürün satın alırken markalar arası fiyat farklılıklarına her zaman } \\
\text { dikkate alııım. }\end{array}$ & 1 & 1.4 & 3 & 4.2 & 6 & 8.5 & 44 & 62.0 & 17 & 23.9 \\
\hline $\begin{array}{l}\text { 9. Yeşil ürünler uzak mağazalarda satılsa bile bu ürünleri satın almay } \\
\text { tercih ederim. }\end{array}$ & 3 & 4.2 & 4 & 5.6 & 31 & 43.7 & 17 & 23.9 & 16 & 22.5 \\
\hline Yeşil Dağıtım & $n$ & $\%$ & $\mathbf{n}$ & $\%$ & $\mathbf{n}$ & $\%$ & $\mathrm{n}$ & $\%$ & $n$ & $\%$ \\
\hline $\begin{array}{l}\text { 10.Firmaların çevreye yönelik uyguladıkları; katı atıkların imhası, } \\
\text { lojistik faaliyetlerde enerji kullanımının azaltılması gibi faaliyetlen } \\
\text { uygulaması çevreye verdikleri önemden kaynaklanmaktadır. }\end{array}$ & 3 & 4.2 & 4 & 5.6 & 14 & 19.7 & 25 & 35.2 & 25 & 35.2 \\
\hline $\begin{array}{l}\text { 11. Çevre kirliğinin en büyük nedenlerinden biri, ürünlerin taşınması } \\
\text { ve dağıtılması sırasında ortaya çıkmaktadır. }\end{array}$ & 1 & 1.4 & 6 & 8.5 & 23 & 32.4 & 25 & 35.2 & 16 & 22.5 \\
\hline $\begin{array}{l}\text { 12. Çevreye zarar vermeyen ürünlerin dağıtımında, ürünlerin en ksa } \\
\text { yoldan bana ulaşmasını tercih ederim. }\end{array}$ & 2 & 2.8 & - & - & 7 & 9.9 & 38 & 53.5 & 24 & 33.8 \\
\hline Yeşil Tutundurma & $\mathrm{n}$ & $\%$ & $\mathrm{n}$ & $\%$ & $\mathrm{n}$ & $\%$ & $\mathrm{n}$ & $\%$ & $\mathrm{n}$ & $\%$ \\
\hline $\begin{array}{l}\text { 13. Ürünün çevre dostu olduğu imajı veren mesajlara sonuna kadar } \\
\text { güveniyorum. }\end{array}$ & 4 & 5.6 & 8 & 11.3 & 18 & 25.4 & 32 & 45.1 & 9 & 12.7 \\
\hline $\begin{array}{l}\text { 14. Yeşil ürünün televizyonda reklamının yapılması o ürünün } \\
\text { güvenilir olduğunun göstergesidir. }\end{array}$ & 10 & 14.1 & 16 & 22.5 & 25 & 35.2 & 16 & 22.5 & 4 & 5.6 \\
\hline $\begin{array}{l}\text { 15. Organik (doğal) ürün satın alma davranışı üze rinde reklamın etkisi } \\
\text { vardır. }\end{array}$ & 6 & 8.5 & 7 & 9.9 & 19 & 26.8 & 27 & 38.0 & 12 & 16.9 \\
\hline $\begin{array}{l}\text { 16. Firmaların çevreciaktivitelerinianlatan mesajları onların çevrenin } \\
\text { korunmasına katkıda bulunduklarının göstergesidir. }\end{array}$ & 4 & 5.6 & 6 & 8.5 & 7 & 9.9 & 38 & 53.5 & 16 & 22.5 \\
\hline
\end{tabular}




\subsection{Yöneticilerin Yeşil Pazarlama Karmasına Yönelik Tutumlarının Demografik Özelliklerine Göre Farklılıklarını Anlamaya Yönelik Analiz Sonuçları}

Mağaza yöneticilerinin yeşil pazarlama karmasına yönelik tutumlarının demografik özellikler açısından genel anlamda anlamlı bir farklılık görülmemiştir. Ancak yeşil pazarlama karması içinde yer alan yeşil ürün ile cinsiyet $(0,008 ; p<0,05)$, yeşil ürün ile gelir $(0,009 ; p<0,05)$, yeşil ürün ile pozisyon $(0,008 ; p<0,05)$ açısından bazı ifadelerde anlamlı farklılıklar görülmektedir. Buna göre kadın Yöneticilerin, 3501 TK ve üzeri geliri olan ve idari pozisyonlardaki yöneticilerin yeşil ürün konusundaki tutumlarının olumlu anlamda daha hassas olduğu gör ülmektedir. Aşağıdaki tablolarda sırasıyla mağaza yöneticilerinin yeşil pazarlama karması tutumlarından yeşil ürün, yeşil fiyat, yeşil dağııım ve yeşil tutundurmanın demografik özellikleri açaısından farklılık gösterip göstermediğine dair bilgiler yer almaktadır.

Tablo 3: Yöneticilerin Yeşil Ürün ile İgili Tutumlarının Demografik Özellikleri Açııından Farklılık Dağı̆ımı Tablosu

\begin{tabular}{|c|c|c|c|c|c|}
\hline ífadeler & \multicolumn{3}{|c|}{ Cinsiyet } & $F$ & $\mathbf{P}$ \\
\hline Yeşil Ürün & Kadın & \multicolumn{2}{|c|}{ Erkek } & & \\
\hline $\begin{array}{lcc}\text { Satın alacağım } & \text { ürünlerin } & \text { içinde } \\
\text { kimyasal katkı } & \text { maddeleri } & \text { olup } \\
\text { olmadığına dikkat ederim. } & \\
\end{array}$ & 2,25 & \multicolumn{2}{|c|}{2,15} & 7,549 & 0,008 \\
\hline Ifadeler & \multicolumn{3}{|c|}{ Gelir } & & \\
\hline Yeşil Ürün & $1500-2500$ & $2501-3500$ & 3501- üzeri & & \\
\hline $\begin{array}{lcc}\text { Satın alacağım } & \text { ürünlerin } & \text { içinde } \\
\text { kimyasal katkı } & \text { maddeleri } & \text { olup } \\
\text { olmadığına dikkat ederim. } & \end{array}$ & 2,85 & 3,93 & 4,32 & 5,085 & 0.009 \\
\hline Ifadeler & \multicolumn{3}{|c|}{ Pozisyon } & & \\
\hline Yeşil Ürün & Orta Düzey Poz. & Üst Düzey Poz. & Idari Personel & $\mathrm{F}$ & $P$ \\
\hline $\begin{array}{l}\text { Ürün satın alırken ambalajındaki } \\
\text { çevresel uyarılara dikkat ederim. }\end{array}$ & 3,52 & 4,12 & 4,61 & 5,175 & 0,008 \\
\hline
\end{tabular}

Tablo 3’ de görüldüğü gibi yeşil ürün tutumlarının demografik özelliklerden cinsiyet, gelir ve pozisyon açısından bazı ifadeler açısından farklııklar görülmektedir. Buna göre yöneticilerin yeşil ürün karması tutumlarında kadınların daha hassas oldukları görülmek tedir. Gelir açısından da belirtilen yeşil ürün ifadesine 3501 TL ve üzeri geliri olanlar daha hassastır.

Tablo 4: Yöneticilerin Yeşil Fiyat ile ilgili Tutumlarının Demografik Özellikleri Açısından Farklılık Dağılımı Tablosu

\begin{tabular}{|c|c|c|c|c|c|}
\hline iffadeler & \multicolumn{3}{|c|}{ Cinsiyet } & $\mathbf{F}$ & $\mathbf{P}$ \\
\hline Yeşil Fiyat & Kadın & \multicolumn{2}{|c|}{ Erkek } & & \\
\hline $\begin{array}{l}\text { Çevreye zararlı bir ürünü fiyatı düşük } \\
\text { olduğu için tercih etmem. }\end{array}$ & 4,67 & \multicolumn{2}{|c|}{4,16} & 9,846 & 0,003 \\
\hline \multicolumn{6}{|l|}{ C } \\
\hline Yeşil Fiyat & $20-29$ & $30-39$ & $40-49$ & $\mathrm{~F}$ & $\mathrm{p}$ \\
\hline $\begin{array}{l}\text { Yeşil ürün alışverişinde fiyatı ne olursa } \\
\text { olsun, güvendiğim ürünü alırım. }\end{array}$ & 3,44 & 4,42 & 4,20 & 5,896 & 0,004 \\
\hline \multicolumn{6}{|c|}{ Pozisyon } \\
\hline Yeşil fiyat & Orta Düzey Poz. & Üst Düzey Poz. & idari Personel & $\mathrm{F}$ & $p$ \\
\hline $\begin{array}{l}\text { Yeşil ürün satın alırken markalar arası } \\
\text { fiyat farklılıklarına her zaman dikkate } \\
\text { alırım. }\end{array}$ & 3,83 & 4,37 & 4,23 & 3,454 & 0,037 \\
\hline
\end{tabular}

Mağaza yöneticilerinin yeşil fiyat tutumlarının demografik özellikler açısından cinsiyet, yaş ve pozisyonda bazı ifadeler açısından farklııklar görülmektedir. Yeşil fiyat tutumununda cinsiyet açısından anlamlı bir farklılık görülmektedir $(0,003 ; p<0,05)$. Yine yeşil fiyat tutumunun yaş $(0,004 ; p<0,05)$ ve pozisyon $(0,037 ; p<0,05)$ bakımından anlamlı bir farklılık taşılığı görülmektedir. Dolayısıyla kadın yöneticilerin ve $30-39$ yaş aralığındaki yöneticilerin yeşil fiyat konusunda ürünler pahalı da olsa yeşil ürünlere güvendikleri için daha çok para ödemeyi diğer katılımcılardan daha fazla kabul ettikleri anlaşılmaktadır. Yine yeşil fiyat tutumu içerisinde yer alan "Yeşil ürün satın alırken markalar aras fiyat farklııklarına her zaman dikkate alıım." şeklindeki İfadeyeüst düzey yöneticilerin katılma oranlarının daha yüksek olduğu görülmektedir.

Tablo 5: Yöneticilerin Yeşil Tutundurma ile ilggili Tutumlarının Demografik Özellikleri Açısından Farklılık Dağııımı Tablosu

\begin{tabular}{|l|c|c|c|c|c|}
\hline Iffadeler & \multicolumn{3}{|c|}{ Gelir } & F & P \\
\hline Yeşil Tutundurma & $1500 \mathrm{TL}-2500 \mathrm{TL}$ & $2501 \mathrm{TL}-3500 \mathrm{TL}$ & $3501 \mathrm{TL}$ ve Üzeri & & \\
\hline
\end{tabular}




\begin{tabular}{|l|l|l|l|l|l|l|l|}
\hline $\begin{array}{l}\text { Organik (doğal) ürün satın alma } \\
\text { davranışı üzerinde reklamın etkisi } \\
\text { vardır. }\end{array}$ & 4,42 & 3,42 & 3,25 & 3,195 & 0,047 \\
\hline Ifadeler & \multicolumn{4}{|c|}{ Pozisyon } \\
\hline Yeşil Tutundurma & Orta Düzey Poz. & Üst Düzey Poz. & \multicolumn{1}{|l|}{ idari Personel } & $\mathrm{F}$ & $\mathrm{p}$ \\
\hline $\begin{array}{l}\text { Organik (doğal) ürün satın alma } \\
\text { davranışı üzerinde reklamın etkisi } \\
\text { vardır. }\end{array}$ & 3,64 & 3,62 & 2,61 & 4,693 & 0,012 \\
\end{tabular}

Mağaza yöneticilerinin yeşil tutundurma tutumlarının demografik özellikler açısından farklılaşıp farklılaşmadığını test etmek amacıyla bağımsız gruplar için T - Testi ve ANOVA Testi yapılmıştır. Yapılan testler sonucunda yöneticilerin, yeşil tutundurma tutumlarının cinsiyet, yaş ve eğitim açısından anlamlı bir farklılık tespit edilemememiştir. Ancak gelir $(0,047 ; p<0,05)$ ve pozisyon $(0,012 ; p<0,05)$ bakımından bazı ifadelerde anlamlı farklııklar tespit edilmiştir.

Tablo 6: Yöneticilerin Yeşil Dağıtım ile İlgili Tutumlarının Demografik Özellikleri Açısından Farklıık Dağıımı Tablosu

\begin{tabular}{|l|l|l|l|l|l|}
\hline İfadeler & \multicolumn{3}{|c|}{ Yaş } & F \\
\hline Yeşil Dağıtım & $\mathbf{2 0 - 2 9}$ & $\mathbf{3 0 - 3 9}$ & $\mathbf{4 0}$ & $\mathbf{5}$ \\
\hline $\begin{array}{l}\text { Firmaların çevreye yönelik } \\
\text { uyguladıkları katı atıkların } \\
\text { imhası, lojistik faaliyetlerde } \\
\text { enerji kullanımının azaltılması } \\
\text { gibi faaliyetleri uygulaması } \\
\text { çevreye verdikleri önemden } \\
\text { kaynaklanmaktadır. }\end{array}$ & & 4,03 & 4,25 & 4,102 & 0,021 \\
\end{tabular}

Yöneticilerin yeşil dağıtımla ilgili "Firmaların çevreye yönelik uyguladıkları; katı atıkların imhası, lojistik faaliyetlerde enerji kullanımının azaltılması gibi faaliyetleri uygulaması çevreye verdikleri önemden kaynaklanmaktadır." ífadesi hakkındaki düşünceleri yaş ba kımından (0, 021; $p<0,05)$ anlamlı farklııı taşıdığı görülmektedir. Bu sonuçlara göre yeşil dağıtımla ilgili yukarıdaki bu ifadeye $40-49$ yaş aralığındakilerin katılım oranlarının diğer yaş grubuna göre daha fazla olduğu anlaşılmaktadır. Dolayısıyla yapılan analizler sonucunda araştırmanın $\mathrm{H}_{1}$, $\mathrm{H}_{2}, \mathrm{H}_{3}$, $\mathrm{H}_{4}, \mathrm{H}_{5}$ hipotezleri desteklenmemiştir.

\section{SONUÇ}

Sürdürülebilir rekabet etmek isteyen, sosyal sorumluluk bilincinde olan, müşterilerin tutumlarını benimseyen işletmelerin yeşil pazarlama karması faaliyetlerini benimsemeleri gerekmektedir. Aynı zamanda yeşil pazarlama, işletme değerini artıran, müşteri sadakati sağlayan ve karlılık getiren bir pazarlama faaliyetidir. Buradan hareketle bu çalışma ile Kocaeli ilindeki bir alış veriş merkezindeki ma ğaza yöneticilerinin yeşil pazarlama karması tutumlarının demografik özellikleri açısından farklılaşıp farklılaşmadığını belirlemek amaçlanmıştır. Bu çalışmada, katılımcıların yöneticiler olarak seçilmesindeki öncelikli amaç, literatürdeki boşluğun doldurulmasının istenmesidir. Aynı zamanda da günümüz teknoloji ve tüketim çağında çevre ile ilgili sorunlar oldukça önemli bir hal almıştır. Işletmelerin ürünlerin üretilmesi için tedarik ettikleri hammadde, yarı mamulden ürünün üretilmesi aşamaları, ürünün satışa sunulmasında uygulanan tutundurma ça baları ve ürünlerin satışa sunulduğu ortamlar bu çevre sorunlarıyla yakındanilgilidir. Bu anlamda işletmelerin üretim sürecinde çevreselkirliliğe neden olmaması, ürünlerin ambalajlarının sağlık açısından zararlı olmayan şekilde tasarlanması, ürünlerin ve ambalajların geri dönüşebilir ürünlerden oluşması ve dağıtım ve tutundurma aşamasında çevreci davranmaları yöneticilerin aldıkları kararlar doğrultusunda gerçekleşmektedir. Çe vreye duyarl bir yöneticininde almış olduğu kararlar toplum yararına olacağından yöneticilerin yeşil pazarlama karması tutumlarının önemli olduğu düşünülmektedir

Çalışmanın sonuçlarına bakıldığında ise genel anlamda yeşil pazarlama karması tutumlarına yönelik verdikleri yanıtlarda yöneticilerin yeşil pazarlama konusunda duyarlı ve olumlu anlamda düşünceleri oldukları anlaşılmaktadır. Bu sonuçların literatür incelemesi sırasındaki çalışmaların sonuçlarına benzemektedir (Karaca, 2013; Çoban ve Sönmez, 2014; Benli vd., 2017). Araştırmanın bulgular bölümünde de değinildiği üzere yöneticilerin yeşil pazarlama karması tutumlarının genel anlamda demografik özellikleri açısından bir farklılık görülmemiştir. Ancak yeşil pazarlama karması içerisindeki yeşil ürün (yeşil ürün ve cinsiyet; yeşil ürün ve pozisyon; yeşil ürün ve gelir), yeşil fiyat (yeşil fiyat ve yaş; yeşil fiyat ve pozisyon; yeşil fiyat ve cinsiyet), yeşil dağıtım (yeşil dağıtım ve yaş) ve yeşil tutundurma (yeşil tu tundurma ve pozisyon; yeşil tutundurma ve gelir) ile ilgili bazı ifadelere verilen yanıtlarda demografik özellikler açısından farklııklar tespit edilmiştir. Araştırmada elde edilen bu farklııkların literatür taraması sırasındaki çalışmalara bazı yönleriyle benzeşmediği görülmektedir. Çoban ve Sönmez (2014) tarafından yapılan araştırmada öğrencilerden oluşan katılımcıların eğitim durumlarına göre yeşil pazarlama karması tutumlarında farklılık görüldüğü tespit edilmiştir. Ancak katılımcıların yöneticilerden oluştuğu bu çalışmada yeşil pazarlama karması elemanlarının eğitim açısından bir farklılık tespit edilememiştir. Bu sonucun farklı statüdeki katılımcılardan kaynaklandığı düşünülmektedir. Ayrıca araştırmanın Çoban ve Sönmez (2014) çalışmalarındaki sonuç kısmında belirtilen ölçeğin farklı örneklem üzerinde değerlendirilmesi öneresinin değerlendirilmiş olması bakımından da anlamlı olduğu düşünülmektedir. Bu anlamda konuyla ilgili daha sonraki yapılacak çalışmalarda bu farklılığın tespiti için farklı illerdeki yöneticiler ve farklı sektörlerdeki yöneticilerle yeşil pazarlama karması ölçeği uygulanabilir. Çalışma Kocaeli ilindeki bir alışveriş merkezi yöneticileri ile kısıtıdır. Bir diğer kısıtı ise çalışmanın 15 Ekim 2019 - 15 Aralık 2019 tarihleri arasında yapılmasıdır. Çalışmanın sonuçları ile yöneticilerin yeşil pazarlama karması tutumları ile demografik özellikleri açısından bir farklılık görülmemektedir şeklinde bir yargıya varılabilmesi için yapılacak çalışmalarda araştırmacılar tarafından ölçeğin yöneticiler açısından değerlendirilmesine ihtiyaç duyulmaktadır. 


\section{KAYNAKÇA}

Aslan, F. (2007). Yeşil Pazarlama Faaliyetleri Çerçevesinde Kafkas Üniversitesi Öğrencilerinin Çevreye Duyarlı Ürünleri Kullanma Eğilimlerini Belirlemeye Yönelik Bir Araştıma, Yüksek Lisans Tezi, Kafkas Üniversitesi Sosyal Bilimler Enstitüsü, Kars.

Ayyıldı, H., Genç, K.Y (2008). Çevreye Duyarlı Pazarlama: Üniversite Öğrencilerinin Çevreye Duyarlı Pazarlama Uygulamaları İle İlgili Tutum Ve Davranışları Üzerine Bir Araştırma. Atatürk Üniversitesi Sosyal Bilimler Enstitüsü Dergisi, 12(2), 505-527.

Benli, T., Karaosmanoğlu, K., Taş Ö. (2017), Çalışan Bireylerin Yeşil Ürün Reklamlarına Yönelik Tutumlarını Etkileyen Faktörlerin Demografik Özelliklerine Göre Farklılıkları, Business \& Management Studies: an International Journal (5), 4, SS. 235-256.

Blend, J.R., Van Ravenswaay, E.O. (1999). Measuring Consumer Demand for Ecolabeled Apples. American Journal of Agricultural Economics: 1072-77.

Boztepe, A. (2012). Green Marketing and İts İmpact on Consumer Buying Behavior, European Journal of Economic and Political Studies, 5(1): 5-21.

Chamorro, A., Bañegil, TM. (2006). Green Marketing Philosophy: a Study of Spanish Firms with Ecolabels. Corporate Social Responsibility and Environmental Management, 13(1), 11-24.

Chang, C.H. (2016). The Determinants Of Green Product Innovation Performance, Corporate Social Responsibility and Environmental Management, Vol. 23, No. 2, 65-76.

Çoban, S., Sönmez, Y. (2014). Yeşil Pazarlama Karmasına Yönelik Tüketici Tutumlarının Demografik Özelliklere Göre Farklılaşması: Ahi Evran Üniversitesi Örneği. Nevşehir Hacı Bektaş Veli Üniversitesi Sosyal Bilimler Enstitüsü Dergisi, 3, 65-82.

Doğan, NS., (2018). Sorumlu Tüketim Davranışı ve Yeşil Pazarlamanın Yöneticilerin Firma Performans Algısına Etkisi, Pamukkale Üniversitesi Sosyal Bilimler Enstitüsü, Yayımlanmış Yüksek Lisans Tezi.

Fuller, D.A. (1999). Sustainable Marketing: Managerial-ecological issues. Sage Publications.

Groening, C., Sarkis, J.,Zhu, Q. (2018). Green Marketing Consumer-Level Theory Review: a Compendium of Applied Theories and Further Research Directions. Journal of Cleaner Production, 172, 1848-1866.

Hasan, Z., Ali, N.A. (2015). The Impact Of Green Marketing Strategy On The Firm's Performance in Malaysia. Procedia-Social and Behavioral Sciences, 172(27), 463-470.

Karaca, S. (2013). Tüketicilerin Yeşil Ürünlere İlişkin Tutumlarının İncelenmesine Yönelik Bir Araştırma/a Research on Investatigation of Consumers' Attitudes on Green Products. Ege Akademik Bakış, 13(1), 99.

Kinoti, M.W. (2011). Green Marketing Intervention Strategies and Sustainable Development: a Conceptual Paper. International Journal of Business and Social Science, 2(23).

Kocaşahin, S.B., (2019), Yeşil Pazarlama Stratejileri: Dünyadaki ve Türkiye'deki Örnek Uygulamaların Karşılaştırılması, KTO Karatay Üniversitesi, Sosyal Bilimler Enstitüsü, Uluslararası Ticaret, Yüksek Lisans Tezi.

Kotler, P., Zaltman, G. (1971). Social Marketing an Approach to Planned Social Change, 35(3), 12.

Murali, K., Lim, M.K., Petruzzi, N.C. (2016). The Effects of Ecolabels and Environmental Regulations on Green Product Development, Manufacturing \& Service Operations Management.

Öndoğan, E.N. (2018). Hazır Giyim Sektörü ve Yeşil Pazarlama. Çukurova Üniversitesi Sosyal Bilimler Enstitüsü Dergisi, 27(2), 97-110.

Papadas, K.K., Avlonitis, G.J., Carrigan, M. (2017). Green Marketing Orientation: Conceptualization, Scale Development and Validation. Journal of Business Research, 80, 236-246.

Peattie, K. (1995). Environmental Marketing Management: Meeting the Green Challenge. Financial Times Management.

Peattie, K. (2001). Golden Goose or Wild Goose? the Hunt for the Green Consumer. Business Strategy and the Environment, 10(4): $187-89$.

Pedro, P.L.J., Lemke, F. (2013). Exploring Green Consumers' Product Demands and Consumption Processes: the Case of Portuguese Green Consumers. European Business Review, 25(3): 281-300.

Rex, E., Baumann, H. (2007). Beyond Ecolabels: What Green Marketing Can Learn From Conventional Marketing, Journal of Cleaner Production, Vol. 15, No. 6, 567-576.

Sharma, Y. (2011). Changing Consumer Behaviour with Respect to Green Marketing-A Case Study Of Consumer Durables and Retailing. International Journal of Multidisciplinary Research, 1(4): 152-62

Simão, L., Lisboa, A. (2017). Green Marketing and Green Brand-The Toyota Case. Procedia Manufacturing, 12, $183-194$.

Soonthonsmai, V. (2007). Environmental or Green Marketing as Global Global Competitive Fdge: Concept, Synthesis, and Implication, Eabr (Business) \&Etlc (Teaching) Conference Proceedings, Venice, Italy. 
Suki, M.N. (2016). Green Product Purchase Intention: Impact of Green Brands, Attitude, and Knowledge. British Food Journal, Vol. 118, No. $12,2893-2910$.

Uysal, O.U. (2006). Yeşil Ürünlerde Konumlandırma ile ilgili Uygulama, Yüksek Lisans Tezi, Marmara Üniversitesi Sosyal Bilimler Enstitüsü, İstanbul.

Varinli, i. (2000). Pazarlama Ahlakı Ve Kayseri’de Küçük ve Orta Ölçekli İşletme Yöneticilerinin Pazarlama Ahlakına İlişkin Değerlendirmeleri. Kayseri Ticaret Odası Yayınları, Yayın, 15.

Zhu, Q., Sarkis, J. (2016). Green Marketing and Consumerism as Social Change in China: Analyzing the Literature. International Journal of Production Economics, 181, 289-302. 